\title{
Efektifitas Daun Sirsak (Anona muricata L) dan Daun Gamal (Gliricidia sepium) dalam Pengendalian Hama Walang Sangit (Leptocorisa acuta T) pada Tanaman padi \\ Effectiveness of Soursop Leaf (Anona muricata L) and Gliricidia Leaf (Gliricidia sepium) to Control Stinky Stinky Pests (Leptocorisa acuta T) on Rice Plants
}

\author{
Midy San Lebang ${ }^{1)^{*}}$, Dantje Taroreh ${ }^{1)}$, Jimmy Rimbing ${ }^{1)}$ \\ 2)Program Studi Entomologi Pascasarjana Universitas Sam Ratulangi Manado \\ Email korespondensi: sanlebang@gmail.com
}

Diterima 12 Agustus 2016, diterima untuk dipublikasikan 27 Agustus 2016

\begin{abstract}
Abstrak
Penelitian ini bertujuan menguji efektifitas ekstrak daun sirsak dan daun gamal sebagai pengendali hama walang sangit pada tanaman padi. Penelitian ini menggunakan Rancangan Acak Lengkap (RAL) dengan 2 perlakuan yaitu jenis ekstrak dan konsentrasi ekstrak. Perlakuan 1 yaitu jenis ekstrak daun (A): sirsak (A1) dan gamal (A2), perlakuan 2 yaitu konsentrasi ekstrak (K): Kontrol (KO), 5\% (K1), 10\% (K2), 15\% (K3), dan 20\% (K4). Hasil penelitian menunjukkan bahwa ekstrak daun sirsak efektif terhadap mortalitas walang sangit tertinggi pada konsentrasi $20 \%$ (83\%) dan yang terendah pada konsentrasi $0 \%$ (0\%). Ekstrak daun gamal juga efektif terhadap mortalitas walang sangit tertinggi pada konsentrasi 20\% (74\%) dan yang terendah pada konsentrasi 0\% (0\%). Waktu kematian pada hari pertama setelah aplikasi dengan rata-rata mortalitas tertinggi berada pada perlakuan ekstrak daun sirsak 20\% (30\%) dan daun gamal 20\% (28\%) dan terendah berada pada perlakuan ekstrak daun sirsak 0\% (0\%) dan daun gamal $0 \%$ (0\%).
\end{abstract}

Kata kunci: daun gamal, daun sirsak, tanaman padi, walang sangit

\section{Abstract}

This study aimed to evaluate the effectiveness of soursop leaf extract and gliricidia leaves as pest control of walang rice (L. acuta) in the rice plants. This study used a completely randomized design (CRD) with 2 treatments, i.e. extract type and extract concentration. The treatment of extract type (A) were soursop (A1) and Gamal (A2), whereas the treatment of extract concentration (K) were control (KO), $5 \%(K 1)$, $10 \%$ (K2), 15\% (K3), and 20\% (K4). The results showed that the soursop leaf extract was effective to control sangit walang with the highest mortality was in the concentration of $20 \%$ (83\%) and the lowest was in the concentration of $0 \%(0 \%)$. Gliricidia leaf extract was also effective to control sangit walang with the highest mortality in the concentration of $20 \%$ (74\%) and the lowest was in the concentration of $0 \%(0 \%)$. The mortality time was on the first day of the application with the average highest mortality was in the treatment of $20 \%$ soursop leaf extract $(30 \%)$ and $20 \%$ gliricidia leaves (28\%) respectively. The lowest mortality was in the treatment of $0 \%$ soursop leaf extract (0\%) and $0 \%$ gliricidia leaves (0\%).

Keywords: gliricidia leaves, rice plant, soursop leaves, walang rice pest 


\section{PENDAHULUAN}

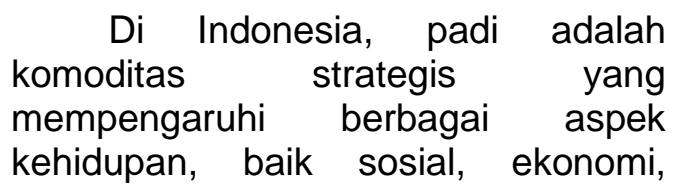
budaya maupun politik. Padi atau beras hingga saat ini masih berperan sebagai pangan utama dan bahkan sebagai sumber perekonomian sebagian besar penduduk di pedesaan. Beras merupakan sumber energi dan protein paling murah, oleh karena itu peranan beras sebagai pangan utama tampaknya sulit tergantikan oleh komoditas pangan lainnya, apalagi tantangan terberat yang dihadapi pemerintah ke depan adalah penyediaan pangan nasional khususnya padi dengan sasaran produksi padi 70,6 juta ton gabah kering giling dan surplus beras 10 juta ton pada tahun 2015.

Tanaman padi merupakan komoditas penting dan strategis bagi pendudk Indonesia karena saat ini hampir $90 \%$ penduduk Indonesia pangannya bersumber dari beras. Peningkatan jumlah penduduk Indonesia sebesar 1,36\% pertahun sehingga diperkirakan pada tahun 2020 dibutuhkan beras sebesar 35,97 juta ton dengan asumsi konsumsi 137 kg/kapita (Irianto 2009), oleh karena itu pemerintah dengan program P2BN tahun 2008 bertekad meningkatkan produksi padi $5 \%$ setiap tahun.

Provinsi Sulawesi Utara Tahun 2014 jumlah produksi padi sawah sebesar 587,009 ton menurun dibandingkan Tahun 2013 sebesar 604,148 ton (BPS Sulut 2015). Salah satu penyebab menurunnya produksi padi adalah munculnya Organisme Pengganggu Tanaman (OPT).

Walang sangit ( $L$. acuta) yang merupakan salah satu hama penting tanaman padi yang menyerang tanaman padi setelah berbunga dengan cara menghisap cairan bulir padi sehingga menyebabkan bulir padi menjadi hampa atau pengisian tidak sempurna. Serangan yang terjadi sebelum matang susu menyebabkan gabah hampa sedangkan serangan pada saat bulir telah berisi sampai menjelang masak menyebabkan gabah berwarna buram sehingga kualitas rendah. Akibat serangan hama ini dapat menurunkan hasil tanaman padi rata-rata $40 \%$ dan serangan berat dapat mencapai 100 \% (Nizar 2011). Tingkat serangan dan menurunnya hasil akibat serangga dewasa lebih besar dibandingkan nimfa. Kerusakan yang tinggi biasanya terjadi pada tanaman di lahan yang sebelumnya banyak ditumbuhi rumput-rumputan serta pada tanaman yang berbunga paling akhir (Willis 2001).

Pengendalian hama walang sangit saat ini umumnya petani menggunakan insektisida sintesis atau kimia karena lebih efektif, cepat diketahui hasilnya dan penerapannya relatif mudah, namun penggunaan insektisida sintesis dapat menimbulkan pengaruh samping yang merugikan, seperti timbulnya resistensi dan resurgensi pada hama sasaran dan terjadinya pencemaran lingkungan Oka 1995).

Pengendalikan hama walang sangit yang ramah lingkungan dan aman untuk kesehatan konsumen maka dipilih pestisida alternatif dengan menggunakan bahan alami yang mempunyai senyawa bioaktif salah satunya adalah tanaman sirsak (Annona muricata L.) dari bagian daunnya dan tanaman gamal (Gliricidia sepium) juga dari bagian daun. Daun sirsak mengandung senyawa kimia antara lain flavonoid, saponin dan steroid yang pada konsentrasi tinggi memiliki keistimewaan sebagai racun perut sehingga menyebabkan hama mengalami kematian (Farnsworth 1996). 
Hasil analisis fitokimia air serbuk daun gamal memperlihatkan ekstrak ini mengandung senyawa metabolit sekunder golongan alkaloid, terpenoid, steroid dan flavonoid dengan kandungan flavonoid paling banyak. Hasil penelitian Nismah et al. (2011). Flavonoid bersifat toksik terhadap hama kutu putih papaya (Paracoccus marginatus).

Penelitian yang dilakukan oleh Padang (2001) didapatkan bahwa ekstrak daun sirsak juga menghambat pertumbuhan dan perkembangan serta dapat mematikan Nimfa $R$. Linearis pada konsentrasi 4,0 \%. Hasil penelitian Shubzan et al. (2012) menunjukkan bahwa ekstrak daun sirsak $100 \mathrm{ml} / \mathrm{L}$ air mampu meningkatkan persentase mortalitas nimfa walang sangit $100 \%$.

Ekstrak daun $A$. muricata juga berpengaruh terhadap mortalitas larva $O$. furnacalis instar III pada tanaman jagung. Konsentrasi ekstrak daun $A$. muricata yang paling berpengaruh terhadap mortalitas larva $O$. furnacalis instar III adalah konsentrasi $40 \%$ dengan tingkat mortalitas $72,5 \%$ (Tenrirawe 2012). Penggunaan ekstrak daun sirsak sebagai pestisida nabati mampu menurunkan jumlah hama Thrips $88 \%$ dengan konsentrasi ekstrak $80 \%$ pada tanaman tomat (Sarmanto 2002).

Ekstrak air tanaman gamal yang dicampurkan dengan detergen dan minyak tanah dapat menekan hama kutu daun kapas setelah 24 jam penyemprotan dan mampu membunuh hama kutu daun sebesar $70 \%$ setelah 48 jam pada skala laboratorium (Tukimin dan Rizal 2002). Hasil penelitian Nismah et al. (2009) menunjukkan ekstrak dengan pelarut etanol dan air daun gamal segar dapat menyebabkan kematian $100 \%$ pada imago hama bisul dadap (Quadrastichus erythrinae) setelah perlakuan 72 jam pada skala laboratorium, sedangkan ekstrak air serbuk daun gamal hasil maserasi bertingkat dengan konsentrasi terendah 2,19\% dapat mematikan 50 $\%$ hama penghisap buah lada (Dasynus piperis) setelah 72 jam perlakuan uji bioassay pada skala laboratorium (Nukmal et al. 2010).

Menghadapi maraknya penggunaan insektisida kimiawi yang dapat membahayakan kesehatan manusia dan sekitarnya serta berdasarkan hasil-hasil penelitian dan beberapa percobaan yang telah dilakukan sebelumnya, maka perlu diuji keefektifan dari pada ekstrak daun sirsak dan daun gamal terhadap hama walang sangit (L. acuta) pada tanaman padi dan hasilnya bisa dimanfaatkan sebagai insektisida nabati.

\section{METODOLOGI PENELITIAN}

Penelitian ini dilaksanakan di Laboratorium Balai Proteksi Tanaman Pangan dan Hortikultura (BPTPH) Sulawesi Utara dan Kantor Balai Pengkajian Teknologi Pertanian (BPTP) Kalasey. Penelitian ini dilaksanakan pada bulan Maret - Juni 2016.

Alat yang digunakan adalah neraca digital GR-200 ( $\delta=0,1 \mathrm{mg})$, blender, pipet Mohr (0,5; 1 ; dan 5) ml, gelas piala, labu ukur, magnetic stirrer TC-2, rotary evaporator Eyela $\mathrm{N}-1000$, digital water bath SB-1000, disk mill FFC-15, labu penyaring, corong pemisah, corong buchner, cawan petri, kertas saring , labu Erlenmeyer, nluminirum fail hotal lom on on lenutnn

54 JURNAL BIOSLOGOS, AGUSTUS 2016, VOL. 6 NO

menulis, kamera, pengukur waktu dan alat bantu lainnya.

Bahan yang digunakan antara lain, methanol $\left(\mathrm{CH}_{3} \mathrm{OH}\right)$, etil asetat $\left(E_{t} \mathrm{OA}_{c}\right)$, n-heksana $\left(\mathrm{C}_{6} \mathrm{H}_{14}\right)$, aquades 
$\left(\mathrm{H}_{2} \mathrm{O}\right)$, tanaman padi, imago walang sangit, daun sirsak, daun gamal dan tanah sawah.

Penelitian ini menggunakan Rancangan Acak Lengkap (RAL) dengan 2 perlakuan yaitu jenis ekstrak dan konsentrasi ekstrak. Perlakuan 1 yaitu jenis ekstrak daun $(A)$ : sirsak (A1) dan gamal (A2), perlakuan 2 yaitu konsentrasi ekstrak (K): Kontrol (K0), 5 $\%$ (K1), $10 \%$ (K2), $15 \%$ (K3), $20 \%$ (K4). Sebagai perlakuan dalam percobaan ini adalah sebagai berikut: $\mathrm{K} 0=$ Kontrol, $\mathrm{A} 1 \mathrm{~K} 1=5 \%$ (ekstrak daun sirsak 0,156 $\mathrm{ml}$ dan 2,969 $\mathrm{ml}$ aquades), $\mathrm{A} 1 \mathrm{~K} 2=10 \%$ (ekstrak daun sirsak 0,312 $\mathrm{ml}$ dan 2,813 $\mathrm{ml}$ aquades), $\mathrm{A} 2 \mathrm{~K} 3=15 \%$ (ekstrak daun sirsak $0,468 \mathrm{ml}$ dan $2,657 \mathrm{ml}$ aquades), A2K4 $=20 \%$ (ekstrak daun sirsak 0,625 ml dan $2,5 \mathrm{ml}$ aquades). $\mathrm{KO}=$ Kontrol ,A2K1 = $5 \%$ (ekstrak daun gamal 0,156 $\mathrm{ml}$ dan 2,969 aquades), A2K2 = $10 \%$ (ekstrak daun gamal $0,312 \mathrm{ml}$ dan 2,813 aquades), $\mathrm{A} 2 \mathrm{~K} 3=15 \%$ (ekstrak daun gamal $0,468 \mathrm{ml}$ dan $2,657 \mathrm{ml}$ aquades), A2K4 = $20 \%$ (ekstrak daun gamal $0,625 \mathrm{ml}$ dan $2,5 \mathrm{ml}$ aquades).

Pelaksanaan penelitian dimulai dengan penanaman bibit padi yang sudah disemai terlebih dahulu sampai berumur 21 hari pada ember kapasitas isi $10 \mathrm{~kg}$ dengan media tanam yaitu tanah sawah sebanyak 25 buah. Setelah memasuki fase generatif diberi sungkup untuk menghindari walang sangit berpindah ke tanaman lain. Sungkup berbentuk segi empat dengan ukuran $50 \times 50 \times 110 \mathrm{~cm}$.

Nimfa walang sangit dipelihara dan disungkup pada pertanaman padi di kantor BPTP Sulawesi Utara lalu diriring untuk memperoleh keseragaman imago. Selanjutnya imago dipindahkan ke tanaman padi yang sudah dipersiapkan untuk aplikasi dan masing-masing sungkup diisi imago walang sangit sebanyak 20 ekor.
Pembuatan

ekstrak menggunakan daun sirsak dan daun gamal dilakukan terpisah yaitu masingmasing sebanyak 1600 gr dicuci bersih, diiris kecil-kecil, kemudian maingmasing direndam dengan pelarut metanol $20 \mathrm{~L}$ selama 24 jam. Larutan disaring menggunakan kertas, kemudian diuapkan dengan menggunakan vacuum rotary evaporator (Buchii/R205). Cairan hasil saringan disatukan dan dimasukkan dalam labu penguap yang telah ditimbang, kemudian methanol diuapkan dengan menggunakan rotary evaporator pada suhu $(45-50)^{\circ} \mathrm{C}$, kecepatan putaran $(50-60) \mathrm{rpm}$, dan tekanan rendah $(150-200) \mathrm{mm} \mathrm{Hg}$. Setelah penguapan selesai, labu berisi ekstrak ditimbang dan selisih antara hasil kedua penimbangan tersebut merupakan bobot ekstrak.

Ekstrak kasar fraksi methanol yang diperoleh dari hasil penguapan dipartisi dalam sistem heksana methanol $(95 \%)$ dengan perbandingan $1: 10: 10(\mathrm{w} / \mathrm{v} / \mathrm{v})$ dalam labu pemisah selama \pm 6 jam, dan fase heksana dicuci dengan methanol $95 \%$. Fase heksana dibuang, sedangkan fase methanol $95 \%$ diuapkan dengan rotary evaporator. Fraksi methanol yang diperoleh kemudian dipartisi kembali dalam sistem etil asetat-air dengan cara seperti tersebut di atas, fase air dibuang dan fase etil asetat diuapkan pelarutnya. Fraksi etil asetat yang diperoleh disimpan dalam lemari es $( \pm$ $\left.4^{\circ} \mathrm{C}\right)$ untuk uji hayati. Ekstrak selanjutnya dilarutkan dengan pelarut akuades dengan konsentrasi $5 \%, 10 \%$, $15 \%$ dan $20 \%$ dan dimasukkan ke dalam handsprayer.

Pengaplikasian dilakukan dengan cara penyemprotan langsung pada tiap sisi sungkup yang berisi imago. Waktu aplikasi ekstrak pada sore hari (jam 16 .00) untuk menghindari terjadinya penguapan. 
Pengamatan dilakukan 24 jam setelah aplikasi dan berlanjut terus menerus selama 5 hari. Pada pengamatan dilakukan perhitungan mortalitas walang sangit dan waktu kematian.

\section{HASIL DAN PEMBAHASAN \\ Pengaruh Ekstrak Daun Sirsak Terhadap Mortalitas Imago Walang Sangit ( $L$. acuta )}

Rata-rata mortalitas imago walang sangit dengan perlakuan konsentrasi ekstrak daun sirsak masing-masing ekstrak menunjukkan perbedaan, dimana mortalitas tertinggi pada perlakuan konsentrasi ekstrak 20 $\%$ dengan rata-rata kematian 83,00\% terendah pada konsentrasi terkecil yaitu kontrol dengan rata-rata kematian $0 \%$. Hal ini menunjukkan bahwa semakin tinggi kepekatan dari konsentrasi ekstrak daun sirsak, maka semakin tinggi pula daya bunuhnya. Menurut Septerina (2002) pada daun sirsak ditemukan senyawa aktif acetogenin, pada konsentrasi tinggi senyawa acetogenin akan bersifat antifeedant (penolak makan) bagi serangga sehingga menyebabkan nafsu makan serangga menurun dan menyebabkan kematian.
Hasil sidik ragam perlakuan konsentrasi daun sirsak menunjukkan perbedaan nyata terhadap mortalitas walang sangit. Pada tabel 1 di atas konsentrasi $0 \%$ berbeda dengan konsentrasi $5 \%, 10 \%$ dan $15 \%$ dan 20 $\%$, sedangkan pada konsentrasi 5 $\%, 10 \%$ dan $15 \%$ tidak menujukkan perbedaan yang nyata, pada konsentrasi $20 \%$ berbeda nyata dengan konsentasi $0 \%, 5 \% .10 \%, 15$ $\%$, karena senyawa aktif dalam daun sirsak bekerja secara efektif dalam mematikan/ mengendalikan hama walang sangit.

Perlakuan kontrol tidak memperlihatkan mortalitas walang sangit dan pada perlakuan ekstrak daun sirsak dengan konsentrasi $5 \%$, $10 \%, 15 \%$ dan $20 \%$ menyebabkan mortalitas walang sangit masingmasing sebesar $55 \%, 57 \%$, $62 \%$ dan $83 \%$. Hal ini menunjukkan bahwa semakin tinggi konsentrasi ekstrak daun sirsak maka semakin tinggi pula mortalitas walang sangit.

Hal ini sesuai dengan Purba (2007) yang menyatakan bahwa peningkatan konsentrasi berbading lurus dengan peningkatan bahan racun tersebut sehingga daya bunuh semakin cepat.

Tabel 1. Rata-rata Mortalitas Imago Walang Sangit L. acuta Setelah Konsentrasi Perlakuan Ekstrak Daun Sirsak

\begin{tabular}{lccc}
\hline No & Perlakuan Konsentrasi (\%) & Mortalitas $(\%)$ & Notasi \\
\hline 1 & 0 (Kontrol) & 0,00 & $\mathrm{a}$ \\
2 & 5 & 55,00 & $\mathrm{~b}$ \\
3 & 10 & 57,00 & $\mathrm{~b}$ \\
4 & 15 & 62,00 & $\mathrm{~b}$ \\
5 & nn & $82 \mathrm{nn}$ & $\mathrm{r}$
\end{tabular}

56 JURNAL BIOSLOGOS, AGUSTUS 2016, VOL. 6 NOMOR 2

Naua lalal i lo

beda nyata

Pengaruh Ekstrak Daun Gamal
Terhadap Mortalitas Imago Walang
Sangit (L. Acuta)
Rata-rata mortalitas imago walang sangit dengan perlakuan konsentrasi ekstrak daun gamal masing-masing ekstrak menunjukkan 
perbedaan, dimana mortalitas tertinggi pada perlakuan konsentrasi ekstrak $20 \%$ dengan rata-rata kematian $74 \%$, sementara yan terendah pada konsentrasi terkecil yaitu kontrol dengan rata-rata kematian $0 \%$. Hal ini menunjukkan bahwa semakin tinggi konsentrasi ekstrak daun gamal, maka semakin tinggi pula daya bunuhnya.

Kemampuan daya bunuh ekstrak daun gamal disebabkan karena adanya kandungan senyawa metabolit sekunder yang bersifat toksik. Salah satunya adalah senyawa flavonoid, senyawa ini diketahui berpotensi sebagai insektisida. Senyawa flavonoid memberikan efek yang bermacam-macam terhadap berbagai macam organisme.

Hama walang sangit yang mati karena diperlakukan dengan ekstrak daun gamal mengalami keracunan perut karena mengisap cairan dari daun gamal yang disemprotkan pada tanaman padi sebagai media uji. Sinaga (2009) menyatakan bahwa kandungan metabolit sekunder pada tanaman seperti glikosida flavonoid bersifat racun perut (stomach poisoning), yang bekerja apabila senyawa tersebut masuk dalam tubuh serangga maka akan mengganggu organ percernaannya. Senyawa flavonoid paling banyak ditemukan pada ekstrak air serbuk daun gamal (Nukmal et al. 2010), sehingga senyawa inilah yang bersifat toksik terhadap hama walang sangit.
Rata-rata persentase mortalitas imago walang sangit L.acuta diaplikasikan dengan ekstrak daun gamal untuk masing-masing perlakuan dapat dilihat pada Tabel 2 . Hasil analisis ragam pada perlakuan ekstrak daun gamal menunjukkan bahwa angka kematian pada tiap-tiap konsentrasi ekstrak daun gamal berbeda nyata. Konsentrasi $0 \%$ berbeda nyata dengan konsentrasi $5 \%$, $10 \%, 15 \%$ dan 20\%. Konsentrasi $5 \%, 10 \%$ dan $15 \%$ tidak menujukkan perbedaan yang nyata sedangkan pada konsentrasi $20 \%$ berbeda nyata dengan konsentasi $0 \%, 5 \% .10 \%, 15 \%$, karena senyawa aktif dalam daun gamal bekerja secara efektif, seperti yang dikemukakan oleh Mulyana (2002) bahwa pemberian konsentrasi yang semakin tinggi, maka semakin banyak zat aktif yang masuk/ terkena dengan serangga.

Perlakuan kontrol tidak memperlihatkan mortalitas walang sangit dan pada perlakuan ekstrak daun gamal dengan konsentrasi $5 \%$, $10 \%$, $15 \%$ dan $20 \%$ menyebabkan mortalitas walang sangit masingmasing sebesar $54 \%$, 58\%, 64\% dan $74 \%$. Hal ini menunjukkan bahwa semakin tinggi konsentrasi ekstrak daun gamal maka semakin tinggi pula mortalitas walang sangit.

Senyawa toksik yang masuk ke dalam tubuh serangga akan mempengaruhi metabolisme dalam tubuhnya. Lu (1994) menyatakan bahwa senyawa yang bersifat 
Tabel 2. Rata-rata Mortalitas Imago Walang Sangit L. acuta Setelah Perlakuan Ekstrak Daun Gamal

\begin{tabular}{llcc}
\hline No & Perlakuan Konsentrasi (\%) & Mortalitas $(\%)$ & Notasi \\
\hline 1 & 0 (Kontrol) & 0,00 & $\mathrm{a}$ \\
2 & 5 & 53,00 & $\mathrm{~b}$ \\
3 & 10 & 58,00 & $\mathrm{~b}$ \\
4 & 15 & 64,00 & $\mathrm{~b}$ \\
5 & 20 & 74,00 & $\mathrm{C}$ \\
\hline
\end{tabular}

BNT $5 \%=12,13$

Ket: Angka-angka yang diikuti dengan huruf yang sama menunjukkan tidak berbeda nyata pada taraf $5 \%$

racun yang masuk ke tubuh akan mengalami biotransformasi menghasilkan senyawa yang larut dalam air dan lebih polar. Proses metabolisme tersebut membutuhkan energi semakin banyak senyawa racun yang masuk ke tubuh serangga menyebabkan energi yang dibutuhkan untuk proses netralisir semakin besar. Banyaknya energi yang digunakan untuk menetralisir senyawa racun tersebut menyebabkan penghambatan terhadap metabolisme yang lain sehingga serangga akan kekurangan energi dan akhirnya mati.

Walang sangit pada perlakuan kontrol tidak mengalami mortalitas karena hanya disemprot dengan air yang tidak mengandung bahan aktif yang bersifat antifeedant terhadap serangga sehingga walang sangit tidak mengalami penurunan aktivitas makan dan terus mengisap biji padi.

\section{Persentase Mortalitas Walang Sangit (L. acuta) menurut Waktu Pengamatan}

Pengambilan data dilakukan pada 1 hari setelah aplikasi (hsa) hingga 5 hsa. Mortalitas tertinggi berada pada 1 hsa pada perlakuan daun sirsak $20 \%$ (30\%) dan gamal 20 $\%(28 \%)$ dan terendah berada pada perlakuan sirsak $0 \%(0 \%)$ dan gamal $0 \% \quad(0 \%)$. Pengamatan pada hari kedua, ketiga, keempat dan kelima setelah aplikasi menunjukkan mortalitas semakin menurun. Hal ini menunjukkan bahwa semakin tinggi konsentrasi perlakuan ekstrak daun sirsak dan daun gamal semakin tinggi persentase mortalitas walang sangit dan waktu kematiannya lebih cepat. Mulyana (2002) dalam Sitompul et al. (2014) menyatakan bahwa semakin tinggi pemberian konsentrasi, maka semakin cepat serangga mati, dikarenakan semakin banyak zat aktif yang masuk/terkena pada serangga.

\section{KESIMPULAN}

1. Ekstrak daun sirsak berpengaruh terhadap mortalitas hama walang sangit pada tanaman padi. Konsentrasi yang paling efektif adalah konsentrasi $20 \%$ dengan tingkat mortalitas $83,00 \%$

2. Ekstrak daun gamal berpengaruh terhadap mortalitas hama walang sangit pada tanaman padi. Konsentrasi yang paling efektif adalah konsentrasi $20 \%$ dengan tingkat mortalitas $74,00 \%$

3. Prosentase mortalitas walang sangit berdasarkan waktu pengamatan adalah 1 hari setelah aplikasi dan terendah 5 hari setelah aplikasi.

\section{DAFTAR PUSTAKA}

Anonim (2003)

Pedoman

Rekomendasi Pengendalian 
Hama Terpadu Pada Tanaman Padi. Direktorat Perlindungan Tanaman, Direktorat Jenderal Bina Produksi Tanaman Pangan. Departemen Pertanian. Jakarta (2015) Sulawesi Utara Dalam Angka. www.bps.go.id. Diakses tanggal 10 Maret 2010

Farnsworth NR (1996) Biological and Phytochemical Screening of Plants, Journal of Pharmaceutical Sciences. 55 (3): 263-275

Irianto GS (2009) Peningkatan Produksi padi melalui IP padi 400. Balai Besar Penelitian tanaman padi. Badan Penelitian dan pengembangan pertanian Jakarta.

Lu FC (1994) Toksikologi Dasar: Asas, Organ sasaran dan Penilaian Resiko. Edisi ke-2. U.I.P. Hal 412.

Mulyana (2002) Ekstraksi Senyawa Aktif Alkaloid,Kuinon dan Saponin dari Tumbuhan Kecubung Sebagai Larvasida dan Insektisida Terhadap Nyamuk Aedes aegypti. Skripsi. Institut Pertanian Bogor. Bogor.

Nizar M ( 2011) Pengaruh Beberapa Jenis Bahan Organik Terhadap Pertumbuhan dan Hasil Tanaman Padi (Oryza sativa L.,) Metode SRI (The System Of Rice Intensification). Skripsi. Universitas Andalas,Padang.

Nismah EL, Widiaastuti dan Sumiyani E (2009) Uji efikasi Ekstrak Daun Gamal (Gliricidia maculata) Terhadap Imago Hama Bisul Dadap (Quadrastichus erythrinae). Prosiding Seminar Nasional XX dan Kongres Biologi Indonesia XIV. Malang 24-25 Juli 2009.
Nismah EL, Utami, N dan Pratami, GD (2011) Isolasi Senyawa Flavonoid dari Ekstrak Air Serbuk Daun Gamal (Gliricidia maculata) dan Uji Toksisitasnya Terhadap Hama Kutu Putih Pepaya (Paracoccus marginatus). Seminar Nasional dan Musyawarah Anggota 2011 Perhimpunan Entomologi Indonesia Cabang Bandung. Bandung 16-17 Februari 2011.

Nukmal N, Utami N dan Suprapto (2010) Skrining Potensi Daun Gamal (Gliricidia maculata Hbr) Sebagai Insektisida Nabati. Laporan Penelitian Hibah Strategi Unila. Universitas Lampung.Lampung

Oka IN (1995) Penggunaan, permasalahan serta Prospek Pestisida Nabati Dalam Pengendalian Hama Terpadu, Bogor.

Padang U (2001) Uji Beberapa Konsentrasi Ekstrak Daun Sirsak (Annona muricata) Terhadap Beberapa Aspek Biologi Riptortus Linearis Fabricius (Hemiptera; coreidae). Jurusan Hama dan Penyakit Tumbuhan Fakultas Pertanian dan Kehutanan UNHAS. Makassar.

Purba S (2007) Uji efektivitas Ekstrak Daun Mengkudu (Morinda citrifolia) Terhadap Plutella xylostella L. (Lepidoptera: Plutellidae) di Laboratorium. Skripsi. Universitas Sumatra Utara. Medan. HIm 29-35.

Sarmanto (2002) Toksisitas Golongan Insektisida dari Ekstrak Bawang Putih dan Daun Sirsak, Pengendalian Hama Tanaman Sayuran dengan Ekstrak Bawang Putih dan Daun Sirsak. 3(2) : 40-43 
Shubzan AM dan Sarni (2012) Efektifitas Ekstrak Insektisida Alami Daun Sirsak Terhadap Mortalitas Hama Walang Sangit (Leptocorisa acuta T) Pada Stadia Ninfa. Primordia Vol.8 No.2 Oktober 2012. Hal.154160.

Septerina NJ (2002) Pengaruh Ekstrak Daun Sirsak Sebagai Insektisida Rasional Terhadap Pertumbuhan dan Hasil Tanaman Paprika Varietas Bell Boy. Dept. of Agronomy (online). Diakses melalui http://digilip.itb.ac.id/gdl.php?m od=browse \&op=read\&id=jiptu mm-gdl-s1-2002-niken-5526ekstrak.

Sinaga R (2009) Uji Efektivitas Pestisida Nabati Terhadap Hama Spodoptra litura (Lepidoptra: Noctuidae) pada Tanaman Tembakau (Nicotiana tabaccum L.). Skripsi. Departemen Ilmu Hama dan Penyakit Tumbuhan Fakultas Pertanian Universitas Sumatera Utara. Medan

Sitompul AF, Syahrial $O$ dan Pangestiningsih Y (2014) Uji Efektifitas Insektisida Nabati terhadap Mortalitas Leptocorisa acuta Thunberg. (Hemiptera : Alydidae) pada Tanaman Padi Oryza sativa L.) di Rumah Kaca. Program Studi Agroekoteknologi, Fakultas Pertanian. Universitas Sumatera Utara. Medan. Jurnal Agroekoteknologi. 2(3): 10751080.

Tenrirawe A (2013) Pengaruh Ekstrak Daun Sirsak (Annona muricata L) terhadap Mortalitas Penggerek Batang (Ostrinia furnacalis G) pada Tanaman Jagung (Zea mays L). Prosiding Seminar Nasional. Balai Besar Pengembangan dan Pengkajian Teknologi Pertanian. Bogor

Tukimin SW dan Molide Rizal (2011) Pengaruh Ekstrak Daun Gamal (Gliricidia Sepium) Terhadap Mortalitas Kutu Daun Kapas Aphis gossypii GLOVER. Balai Penelitian Tanaman Rempah dan Aromatik. Bogor

Willis M (2001) Hama dan Penyakit Utama Padi di Lahan Pasang Surut. Monograf. Badan Litbang Pertanian. Balittra. Banjarbaru 